\title{
Use of allogeneic tissue to treat infective valvular disease: Has everything been said?
}

\author{
Francesco Nappi, MD, ${ }^{\mathrm{a}}$ Cristiano Spadaccio, $\mathrm{MD}, \mathrm{PhD},{ }^{\mathrm{b}, \mathrm{c}}$ and Christophe Acar, $\mathrm{MD}, \mathrm{PhD}^{\mathrm{d}}$
}

\footnotetext{
From the ${ }^{\mathrm{a} C a r d i a c}$ Surgery Center, Cardiologique du Nord de Saint-Denis; ${ }^{\mathrm{b}}$ Department of Cardiothoracic Sur-

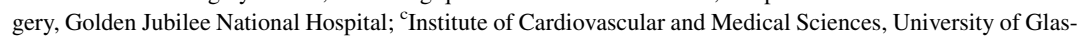
gow, Glasgow, United Kingdom; and ${ }^{\mathrm{d}}$ Department of Cardiovascular Surgery, Hôpital de la Salpétrière, Paris, France.

Received for publication Aug 8, 2016; revisions received Sept 21, 2016; accepted for publication Sept 26, 2016; available ahead of print Nov 17, 2016

Address for reprints: Francesco Nappi, MD, Cardiologique du Nord de Saint-Denis, 36 Rue des Moulins Gémeaux, 93200 Saint-Denis, France (E-mail: francesconappi2@ gmail.com).

J Thorac Cardiovasc Surg 2017;153:824-8

$0022-5223 / \$ 36.00$

Copyright (c) 2016 by The American Association for Thoracic Surgery

http://dx.doi.org/10.1016/j.jtcvs.2016.09.071
}

Heart surgery does not always walk forward. It occasionally stops, sometimes retraces its steps. Recently, after the appearance of some interesting reports on the use of homografts for aortic infective endocarditis (IE), it has made quite a jump backward, returning to the situation faced at least 15 years ago. Kim and colleagues ${ }^{1}$ questioned the benefit of homografts in aortic position based on the results of a propensity-matched analysis comparing homografts, xenografts, and mechanical prostheses in the setting of IE showing no demonstrable benefit in terms of mortality and resistance to reinfection in the homograft group.

The use of allograft substitutes or autografts is not uniform across European and American units and is greatly dependent on surgeons' individual experience and training. Indeed, as mentioned by Kim and colleagues ${ }^{1}$ and in a subsequent editorial by Kirklin, ${ }^{2}$ the technical challenge and the lack of training in these techniques over the last 10 years, coupled with the absence of readily available homograft valves at many centers, has restricted the widespread use of this substitute, confining the "art" of homograft surgery to the hands of a small group of surgeons. ${ }^{2}$ Regardless of these caveats, however, it is undeniable that when such factors as the severity of the destructive process or its extension to the mitral valve are involved, the balance in the choice of the most suitable substitute is critically weighted toward homografts over conventional stented or mechanical prostheses.

The study by Kim and colleagues, ${ }^{1}$ although a notable and well-designed contribution, bases its conclusions on a maximum follow-up of 72 months. This hardly compares with the 15- or 20-year follow-up in the studies by Musci and colleagues ${ }^{3}$ and Yankah and colleagues, ${ }^{4}$ which is of significance when comparing homografts with xenografts or mechanical valves, given that the actual clinical benefit from the use of homografts is expected to emerge in the long term rather than in the short term (ie, better hemodynamics, no warfarin-related complications). In addition,

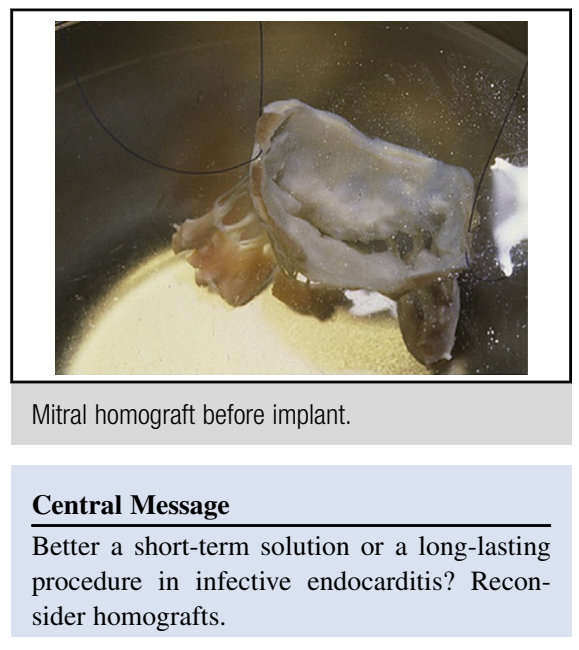

See Editorial Commentary page 829

there was a significant imbalance in the indication for use of homografts, xenografts, and mechanical valves, with the homografts implanted in patients with significantly more serious and complex conditions, including annular abscess, mitral valve involvement, aortomitral junctional abscess, and prosthetic IE. In their propensity score matching analysis, homograft use did not produce a significant benefit in terms of mortality.

The foregoing results seem to challenge the idea introduced by Barratt-Boyes in 1967, and subsequently refined by Ross, Jacoub, and O'Brien, on the use of homografts in patients with IE. ${ }^{5-9}$ Indeed, for similar patients with IE with differing degrees of extension of the lesion and aggression of the aortic valve, several pivotal observational studies have shown that the use of cryopreserved homograft provides a survival benefit over conventional valve replacement. Successful treatment of circumferential annular abscess root replacement or aortomitral junction abscess using aortic homografts has been reported. ${ }^{10-12}$ In 2002, Yankah and colleagues ${ }^{4}$ reported on a 10-year follow-up of 816 patients presenting with complex aortic root IE with periannular abscess and implanted with

Scanning this QR code will take you to a video for the article.

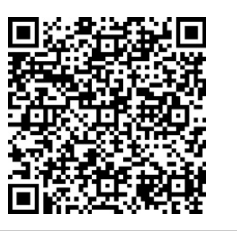




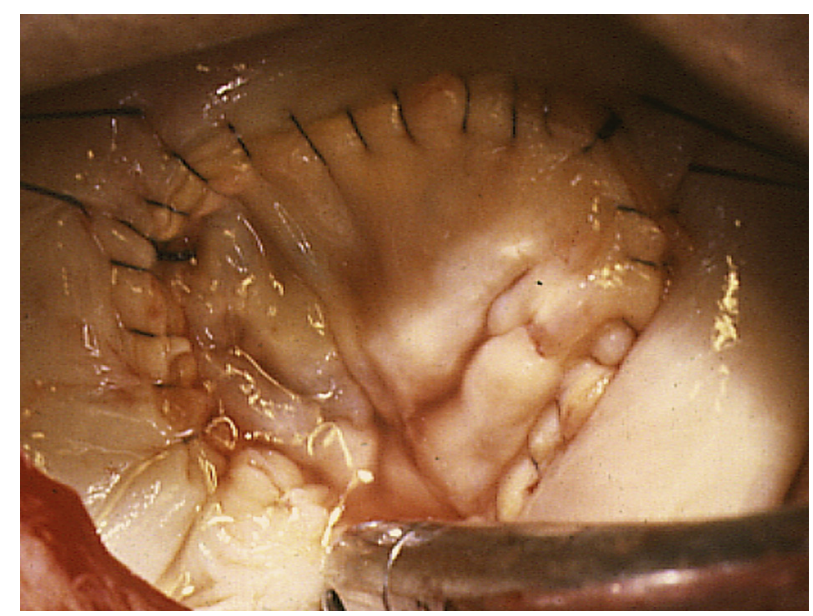

FIGURE 1. Total homograft replacement of the mitral valve after destructive endocarditis with involvement of the entire mitral annulus.

cryopreserved homografts, showing a survival of $91 \%$ with a reinfection rate of $3.6 \%$ at 10 years. The authors concluded that a properly inserted homograft could provide excellent hemodynamics with reduced risk of reinfection, and that only an undersized mismatch was an actual determinant of reoperation risk. ${ }^{4}$ In 2010, Musci and colleagues, ${ }^{3}$ in a series including patients with native valve endocarditis, prosthetic valve endocarditis (PVE) and aortoventricular dehiscence, demonstrated satisfactory early and long-term results with a similar low risk of infection recurrence. This was thought to be related to the complete eradication of the infection that is possible with homograft implantation. The use of homografts also would be appropriate in cases of severe destructive endocarditis with aortoventricular dehiscence when reconstruction of the left ventricular outflow tract is required. Musci and colleagues ${ }^{3}$ reported significantly better outcomes in patients with native valve endocarditis compared with those with PVE. In the context of PVE, Perrotta and colleagues ${ }^{13}$ recently reported their 20 years of experience with homografts and compared outcomes with those of mechanical and biological valves, and documented no significant difference in early mortality or 10 -year survival rate, but a statistically significantly lower rate of infection recurrence, with homografts.

This finding supports the widely accepted assumption that antibiotics are more effective in living and wellvascularized tissue, explaining the higher incidence of recurrent infection in patients who received synthetic derivatives compared with those who received biological allogeneic substitutes. In particular, some strains of Staphylococcus aureus and Streptococcus viridans are known to be extremely aggressive, with the latter being difficult to detect even with the use of sophisticated techniques, such as mpB genotyping and matrix-assisted laser desorption/ ionization time-of-flight systems. ${ }^{14}$ In the study by Kim

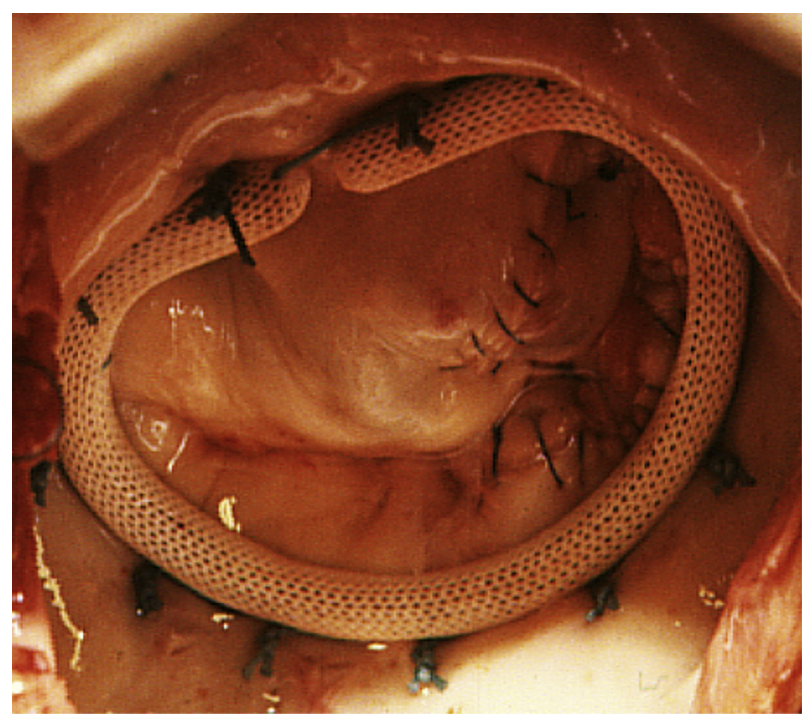

FIGURE 2. Partial homograft replacement of the mitral valve after extensive endocarditis with commissural lesion.

and colleagues, ${ }^{1} S$ viridans was isolated in the $38 \%$ of the patients who received a mechanical valve. In these conditions, the decision to implant a mechanical valve should be carefully considered given the high rate of recurrence and the elevated risk of mortality after reinfection. In this context, an interesting study conducted in a community hospital serving a highly diverse population in New York City, which captured a real-life picture of patients with IE based on modified Duke criteria, revealed a mortality rate of $27.7 \%$ in patients with prosthetic heart valves, compared with only $8.11 \%$ in patients with native heart valves. ${ }^{15}$

\section{ENDOCARDITIS EXTENSION AND MITRAL VALVE INVOLVEMENT}

Another important question is related to the complexity and extension of the infection in IE. If in cases of localized leaflet involvement with vegetations smaller than $10 \mathrm{~mm}$, the question of whether a standard aortic valve replacement will suffice instead of a more destructive approach remains reasonable, then in cases of large abscess formation and extensive annular disease, the need for an appropriate clearance of the infected tissue and adequate reconstruction of the aortic root is more compelling. Kim and colleagues ${ }^{1}$ treated more than $40 \%$ of patients presenting with abscess formation with mechanical prostheses, which on one hand provides a relatively quick and uncomplicated solution in the short-term, but on the other hand implies accepting the long-term risk of valve reinfection in this more complex operation. In this light, what is the actual benefit of limiting immediate surgery to valve replacement and extending it to more difficult procedures in the long-term?

A similar question might be posed in cases of IE involving the mitral valve alone or in combination with 


\section{The aortic valve homograft}

\author{
Use of allogeneic tissue to treat \\ infective valvular disease. Has \\ everything been said?
}

VIDEO 1. The main aspects of homograft evolution, advantages and disadvantages, and indications for use. Video available at: http://www. jtcvsonline.org/article/S0022-5223(16)31397-6/addons.

aortic structures. An analysis of the profiles of IE and surgical procedures published by Kim and colleagues (their Table 2$)^{1}$ reveals mitral valve involvement in a more than onehalf of their 56 patients treated with valve prostheses, including 30 patients with a mechanical valve $(38.0 \%)$ and 26 patients with a stented xenograft $(18.7 \%)$ respectively. The 26 patients treated with a xenograft had a follow-up of 72 months, a relatively short and scarcely informative time frame for homografts, compared with other studies reporting outcomes at up to 18 years after treatment. ${ }^{16}$ In addition, from a technical standpoint, Obadia and colleagues proposed the use of a monobloc aortomitral homograft in cases of extensive IE involving the aortic root and aortomitral curtain. ${ }^{17}$

We also found 11 double homograft valve replacements, including 8 cases of double homograft separate bloc with total mitral homograft implantation and 3 cases of double homograft separate bloc with partial mitral homograft insertion (Figures 1 and 2). However, in our experience we prefer an approach using separate aortic and mitral homografts, which reduces the risk of size mismatch and precludes the need for any reconstruction of the left atrial roof. ${ }^{18}$ This approach is normally coupled with the implantation of a prosthetic ring in the mitral homograft, which was found to increase the durability of the mitral homograft in our 8-year follow-up study on mitral homograft replacement. ${ }^{19}$ The implantation technique of intraventricular fixation in a side-to-side position on the recipient papillary muscle has provided good results even when mitral tissue is more fragile owing to the presence of infection, ${ }^{20,21}$ with a lower incidence of papillary muscle rupture than has been reported in other series. ${ }^{22,23}$

Beginning with one of the first implantations in 1994, ${ }^{24}$ our group has acquired extensive experience in the use of mitral homografts, especially in cases of endocarditic etiology. ${ }^{16,20,21}$ In contrast with Kim and colleagues, ${ }^{1}$ in our experience the long-term clinical results of mitral homograft implantation are very encouraging, with rates of freedom from structural valve deterioration (SVD) of $90 \%$ at 5 years, $76 \%$ at 10 years, and $65 \%$ at 15 years and of freedom from reoperation of $88 \%$ at 5 years, $80 \%$ at 10 years, and $64 \%$ at 15 years. ${ }^{16}$ The endocarditic etiology, the surgical technique (total vs partial homograft), the size of the prosthetic ring ( $30 \mathrm{~mm}$ vs larger), and the association with aortic valve surgery were identified as independent predictors of reoperation, although children (age $<18$ years) had a greater risk of reoperation. SVD resulted in mixed stenosis and insufficiency and was more frequent in patients with a total homograft $(P=.018$ vs partial homograft), patients with a nonendocarditic etiology $(P=.02$ vs endocarditis) and patients who have experienced pregnancy ( $P=.016$ vs no pregnancy). ${ }^{16,25}$

Similar results were obtained in another mitral series from Yankah and colleagues, ${ }^{23}$ as well as in a study of the use of mitral homografts in the tricuspid position from Mestres and colleagues, ${ }^{26}$ and also in a study on growing animals reported by Bernal and colleagues. ${ }^{27}$ On this basis, the findings of comparable results with mitral homografts and bioprostheses in a cohort of young patients, ${ }^{19}$ along with the effectiveness of these biosubstitutes in young females desiring future pregnancy, ${ }^{28,29}$ make homografts an attractive alternative in our opinion.

\section{UNANSWERED QUESTIONS AND FUTURE DIRECTIONS}

Undoubtedly, compared with aortic valve replacement, mitral valve replacement with a cryopreserved homograft is more limited in scope and indications, owing mainly to differences in etiology. Indeed, the last several decades has seen a shift in mitral valve disease from a rheumatic to a degenerative etiology, which is best addressed by mitral repair techniques. However, the pathology of IE in children necessitating the use of a substitute that can accommodate the patient's somatic growth remains an important indication for both mitral repair and valve substitutes, as specified by American and European guidelines. ${ }^{30,31}$

Of note, these guidelines also reflect a parallel renewed interest in stented xenograft prostheses in the aortic position for patients aged $<65$ years. This orientation is supported by the benefits of biological substitutes in terms of good durability and no need for anticoagulation, and by the possibility of valve-in-valve transcatheter aortic valve replacement in cases of SVD. ${ }^{32}$ In this context, cryopreserved homografts have already shown not only similar beneficial effects on hemodynamic performance, but also consistent advantages over conventional prostheses, stented xenografts, and mechanical valves in terms of low thrombogenicity, avoidance of life-long anticoagulation, lower rate of neurologic events, improved quality of life during the reproductive years, and risk of reinfection. ${ }^{33,34}$ Moreover, the recent achievements in terms of antibiotic management, pathogenic diagnosis, ${ }^{35}$ and novel anticoagulants ${ }^{36}$ surely will play a role in the management of IE (Video 1).

As noted by Stulak and colleagues ${ }^{37}$ with regard to the use of autologous and allogeneic substitutes to treat both congenital and acquired disease of the left ventricular outflow tract, the use of biological derivatives raises some 
ethical issues when the risk of procedure failure or of reoperation is not low. Our group also has faced the problem of longevity of biological substitutes, and has attempted to provide reasonable approaches to dealing for these substitutes' long-term drawbacks. ${ }^{38-40}$ Patients need to be informed in detail about the technical issues associated with the use of homografts. As recommended by current guidelines, multidisciplinary decision making regarding valve replacement strategies in IE should take into account the longevity of the biological substitute, the potential recurrence of infection, and the possible need for repeat surgery, which is often associated with extensive cardiac tissue destruction. This is not only required, but emphasized. The choice is best made through a process of shared decision making that includes the patient, the patient's family, an interventional cardiologist, a cardiac surgeon, and as preferred, the patient's general cardiologist or primary care practitioner. In the context of homograft implantation, striking a balance between the risk of SVD with potential valve dysfunction versus a very low incidence of infection recurrence, which would require further complex redo surgery and tissue destruction, should be taken into account when discussing surgical options with the patient.

On the other hand, SVD and calcification of homograft aortic wall is a major drawback of the use of these conduits, leading to technically demanding reoperation with a reported mortality of $4 \%$ to $10 \%$ and morbidity of $34 \% .{ }^{41}$ However, unlike prosthetic valves, homografts are affected by reinfection only very rarely, and SVD occurring in homografts carries a significantly lower burden $(8.9 \%$ early mortality in the series reported by Kowert and colleagues ${ }^{42}$ ) compared with redo surgery for an infected prosthetic valve, as exemplified by the $17 \%$ operative mortality reported by Grubitzch and colleagues. ${ }^{43}$ Indeed, novel transcatheter procedures might be performed with relatively low risk in cases of homograft calcification; for example, Kowert and colleagues ${ }^{42}$ reported $86 \%$ survival at 1 year and $77.4 \%$ survival at 5 years after homograft redo operation, and deemed transcatheter aortic valve replacement (TAVR) a safe and feasible option in cases where the valve is not infected. However, TAVR is not indicated in cases of noncalcified annuli with massive valve regurgitation, in which treatment for SVD necessitates surgical replacement of the conduit. It has been suggested that in patients with noncalcified annulus and regurgitation (eg, cusp prolapse, cusp rupture) secondary to homograft degeneration, the use of a sutureless valve is a viable option, especially in younger patients ${ }^{44,45}$ and also in patients with homograft reinfection, ${ }^{46}$ whereas TAVR might be safely performed in patients with noninfected calcified SVD with reduced mortality and morbidity. ${ }^{47}$

Nonetheless, evidence suggests that in complex valve surgery for IE, SVD is a much less daunting problem than recurrent infection. The reoperation for relapsing infection, especially when extended or circumferential abscesses have been treated with prosthetic valves and large amounts of prosthetic materials, such as Dacron patches, is technically demanding and associated with higher mortality. The use of homografts is a reasonable option in cases of extensive abscess, either circumferential (as is typical in cases of PVE) or deep in the aortomitral curtain and interventricular septum. Moreover, homografts have been shown to be useful in cases of relapsing infection after a David or Bentall operation for root endocarditis. ${ }^{48}$ However, in cases of less aggressive lesions and vegetations smaller than $10 \mathrm{~mm}$, the use of allogeneic tissue is recommended only in the pediatric population when necessary to accommodate somatic growth (Video 1).

In conclusion, regardless of the important limitations related to the lack of surgical training and inconsistent homograft availability, in patients with IE, the choice between a short-term solution burdened by the risk of reinfection (ie, xenograft or mechanical valve) and a more surgically demanding but longer-lasting procedure (ie, homograft) should be carefully weighed and serve as the main topic of discussion in cardiac teams.

In other words, should we more often apply the maxim "do it once, and do it well" in extensive IE?

\section{Conflict of Interest Statement}

Authors have nothing to disclose with regard to commercial support.

\section{References}

1. Kim JB, Ejiofor JI, Yammine M, Camuso JM, Walsh CW, Ando M, et al. Are homografts superior to conventional prosthetic valves in the setting of infective endocarditis involving the aortic valve? J Thorac Cardiovasc Surg. 2016;151: 1239-46. 1248.e1-2.

2. Kirklin JK. Challenging homografts as the holy grail for aortic valve endocarditis. J Thorac Cardiovasc Surg. 2016;151:1230-1.

3. Musci M, Weng Y, Hübler M, Amiri A, Pasic M, Kosky S, et al. Homograft aortic root replacement in native or prosthetic active infective endocarditis: twentyyear single-center experience. J Thorac Cardiovasc Surg. 2010;139:665-73.

4. Yankah AC, Klose H, Petzina R, Musci M, Siniawski H, Hetzer R. Surgical management of acute aortic root endocarditis with viable homograft: 13-year experience. Eur J Cardiothorac Surg. 2002;21:260-7.

5. Ross DN. Aortic valve surgery. Ann R Coll Surg Engl. 1966;39:192-7.

6. Ross D, Yacoub MH. Homograft replacement of the aortic valve. A critical review. Prog Cardiovasc Dis. 1969;11:275-93.

7. Yacoub MH, Kittle CF. A new technique for replacement of the mitral valve by a semilur valve homograft. J Thorac Cardiovasc Surg. 1969;58:859-69.

8. Paneth M, O'Brien MF. Transplantation of human homograft aortic valve. Tho$\operatorname{rax} .1966 ; 21: 115-7$.

9. O'Brien MF. Homograft replacement of the aortic valve. Ann Thorac Surg. 1992; 53:928-9.

10. Bakaeen FG, Walkes JC, Reardon MJ. Stentless bioprosthetic aortic valve replacement after a homograft root replacement: Toronto SPV implantation after a homograft root. Ann Thorac Surg. 2005;79:1397-9.

11. Pereda D, Park SJ. "Freezing" the left ventricular outflow tract for homograft reconstruction in aortic root endocarditis. J Thorac Cardiovasc Surg. 2011 141:301-3.

12. Sung K, Lee YT, Park PW, Park KH, Jun TG, Yang JH. Minimizing foreign material in the reconstruction of infected complex annuloaortic disruption. Ann Thorac Surg. 2004;78:2191-2. 
13. Perrotta S, Jeppsson A, Fröjd V, Svensson G. Surgical treatment of aortic prosthetic valve endocarditis: a 20-year single-center experience. Ann Thorac Surg. 2016;101:1426-32.

14. Isaksson J, Rasmussen M, Nilson B, Stadler LS, Kurland S, Olaison L, et al Comparison of species identification of endocarditis associated viridans streptococci using rnpB genotyping and 2 MALDI-TOF systems. Diagn Microbiol Infect Dis. 2015;81:240-5.

15. Alkhawam H, Sogomonian R, Zaiem F, Vyas N, El-Hunjul M, Jolly J, et al Morbidity and mortality of infective endocarditis in a hospital system in New York City serving a diverse urban population. J Investig Med. 2016;64: 1118-23.

16. Olivito S, Lalande S, Nappi F, Hammoudi N, D'Alessandro C, Fouret P, et al Structural deterioration of the cryopreserved mitral homograft valve. J Thorac Cardiovasc Surg. 2012;144:313-20. 320.e1.

17. Obadia JF, Hénaine R, Bergerot C, Ginon I, Nataf P, Chavanis N, et al. Monobloc aorto-mitral homograft or mechanical valve replacement: a new surgical option for extensive bivalvular endocarditis. J Thorac Cardiovasc Surg. 2006;131:243-5.

18. Acar C. Monobloc or separate aortic and mitral homografts? J Thorac Cardiovasc Surg. 2006;132:442-3; author reply 3.

19. Ali M, Iung B, Lansac E, Bruneval P, Acar C. Homograft replacement of the mitral valve: eight-year results. J Thorac Cardiovasc Surg. 2004;128:529-34.

20. Acar C, Tolan M, Berrebi A, Gaer J, Gouezo R, Marchix T, et al. Homograft replacement of the mitral valve: graft selection, technique of implantation, and results in forty-three patients. J Thorac Cardiovasc Surg. 1996;111:367-78; discussion 378-80.

21. Doty DB, Acar C. Mitral valve replacement with homograft. Ann Thorac Surg. 1998;66:2127-31.

22. Kumar AS, Choudhary SK, Mathur A, Saxena A, Roy R, Chopra P. Homograft mitral valve replacement: five years' results. J Thorac Cardiovasc Surg. 2000; 120:450-8.

23. Yankah AC, Sievers HH, Lange PE, Bernhard A. Clinical report on stentless mitral allografts. J Heart Valve Dis. 1995;4:40-4.

24. Acar C, Farge A, Ramsheyi A, Chachques JC, Mihaileanu S, Gouezo R, et al Mitral valve replacement using a cryopreserved mitral homograft. Ann Thorac Surg. 1994;57:746-8.

25. Nappi F. CRT-721 The cryopreserved mitral homograft valve: 19 years' experience. JACC Cardiovasc Interv. 2014;7:S58.

26. Mestres CA, Castellá M, Moreno A, Paré JC, del Rio A, Azqueta M, et al. Cryopreserved mitral homograft in the tricuspid position for infective endocarditis: a valve that can be repaired in the long term (13 years). J Heart Valve Dis. 2006;15: 389-91.

27. Bernal JM, Rabasa JM, Cagigas JC, Val F, Revuelta JM. Behavior of mitral allografts in the tricuspid position in the growing sheep model. Ann Thorac Surg. 1998; 65:1326-30.

28. Nappi F, Spadaccio C, Chello M, Lusini M, Acar C. Impact of structural valve deterioration on outcomes in the cryopreserved mitral homograft valve. J Card Surg. 2014;29:616-22.

29. Sadler L, McCowan L, White H, Stewart A, Bracken M, North R. Pregnancy outcomes and cardiac complications in women with mechanical, bioprosthetic and homograft valves. BJOG. 2000;107:245-53.

30. Habib G, Lancellotti P, Antunes MJ, Bongiorni MG, Casalta JP, Del Zotti F, et al Task Force for the Management of Infective Endocarditis of the European Soci- ety of Cardiology. 2015 ESC guidelines for the management of infective endocarditis. Eur Heart J. 2015;36:3075-128.

31. Byrne JG, Rezai K, Sanchez JA, Bernstein RA, Okum E, Leacche M, et al. Surgical management of endocarditis: the Society of Thoracic Surgeons clinical practice guideline. Ann Thorac Surg. 2011;91:2012-9.

32. Bourguignon T, Bouquiaux-Stablo AL, Candolfi P, Mirza A, Loardi C, May MA, et al. Very-long-term outcomes of the Carpentier-Edwards Perimount valve in aortic position. Ann Thorac Surg. 2015;99:831-7.

33. Takkenberg JJ, van Herwerden LA, Eijkemans MJ, Bekkers JA, Bogers AJ. Evolution of allograft aortic valve replacement over 13 years: results of 275 proced ures. Eur J Cardiothorac Surg. 2002;21:683-91; discussion 691.

34. Nappi F, Al-Attar N, Spadaccio C, Chello M, Lusini M, Acar C. Aortic valve homograft: 10-year experience. Surg Technol Int. 2014;24:265-72.

35. Ferro JM, Fonseca AC. Infective endocarditis. Handb Clin Neurol. 2014;119 75-91

36. Basaran Ö, Dogan V, Sahin C, Biteker M. Non-vitamin K antagonist oral anticoagulants in valvular atrial fibrillation. Int J Cardiol. 2016;212:357.

37. Stulak JM, Burkhart HM, Sundt TM III, Connolly HM, Suri RM, Schaff HV, et al Spectrum and outcome of reoperations after the Ross procedure. Circulation 2010;122:1153-8

38. Nappi F, Spadaccio C, Fraldi M, Montagnani S, Fouret P, Chachques JC, et al. A composite semiresorbable armoured scaffold stabilizes pulmonary autograft after the Ross operation: Mr Ross's dream fulfilled. J Thorac Cardiovasc Surg. 2016:151:155-64.e1.

39. Nappi F, Spadaccio C, Chello M, Acar C. The Ross procedure: underuse or un der-comprehension? J Thorac Cardiovasc Surg. 2015;149:1463-4.

40. Nappi F, Spadaccio C, Fouret P, Hammoudi N, Chachques JC, Chello M et al. An experimental model of the Ross operation: development of resorbable reinforcements for pulmonary autografts. J Thorac Cardiovasc Surg. 2015;149:1134-42.

41. Joudinaud TM, Baron F, Raffoul R, Pagis B, Vergnat M, Parisot C, et al. Redo aortic root surgery for failure of an aortic homograft is a major technical challenge. Eur J Cardiothorac Surg. 2008;33:989-94.

42. Kowert A, Vogt F, Beiras-Fernandez A, Reichart B, Kilian E. Outcome after homograft redo operation in aortic position. Eur J Cardiothorac Surg. 2012;41 404-8.

43. Grubitzsch H, Christ T, Melzer C, Kastrup M, Treskatsch S, Konertz W. Surgery for prosthetic valve endocarditis: associations between morbidity, mortality and costs. Interact Cardiovasc Thorac Surg. 2016;22:784-91.

44. Folliguet TA, Laborde F. Sutureless Perceval aortic valve replacement in aortic homograft. Ann Thorac Surg. 2013;96:1866-8.

45. Folesani G, Calcara G, Minniti G, Polesel E. Reoperation for aortic homograf failure using an Edwards Intuity valve. Interact Cardiovasc Thorac Surg. 2016;22:378-80.

46. Gupta P, McCormack DJ, Szczeklik M, Ambekar S, Lall KS. Infected calcified homograft root: a sutureless solution. Ann Thorac Surg. 2013;95:1789-91.

47. Dainese L, Fusari M, Trabattoni P, Biglioli P. Redo in aortic homograft replacement: transcatheter aortic valve as a valid alternative to surgical replacement. $J$ Thorac Cardiovasc Surg. 2010;139:1656-7.

48. d'Alessandro C, Vaquette B, Acar C. Recurrent aortic pseudoaneurysm following David and Bentall operations treated by homograft replacement. J Heart Valve Dis. 2010;19:152-3. 